University of Nebraska - Lincoln

DigitalCommons@University of Nebraska - Lincoln

2020

\title{
Clinical and pharmaceutical applications of affinity ligands in capillary electrophoresis: A review
}

Chenhua Zhang

Ashley G. Woolfork

Kyungah Suh

Susan Ovbude

Cong $\mathrm{Bi}$

See next page for additional authors

Follow this and additional works at: https://digitalcommons.unl.edu/chemistryhage

Part of the Medicinal-Pharmaceutical Chemistry Commons

This Article is brought to you for free and open access by the Published Research - Department of Chemistry at DigitalCommons@University of Nebraska - Lincoln. It has been accepted for inclusion in David Hage Publications by an authorized administrator of DigitalCommons@University of Nebraska - Lincoln. 
Authors

Chenhua Zhang, Ashley G. Woolfork, Kyungah Suh, Susan Ovbude, Cong Bi, Marawan Elzoeiry, and David S. Hage 


\title{
Clinical and pharmaceutical applications of affinity ligands in capillary electrophoresis: A review
}

\author{
Chenhua Zhang, Ashley G. Woolfork, Kyungah Suh, \\ Susan Ovbude, Cong Bi, Marawan Elzoeiry, and \\ David S. Hage
}

Department of Chemistry, University of Nebraska-Lincoln, Lincoln, NE, 68588-0304, USA

Corresponding author - D.S. Hage, 704 Hamilton Hall, Chemistry Department, University of Nebraska-Lincoln, Lincoln, NE 68588-0304 USA. Email dhage1@unl.edu

\begin{abstract}
Affinity capillary electrophoresis (ACE) is a separation technique that combines a biologically-related binding agent with the separating power and efficiency of capillary electrophoresis. This review will examine several classes of binding agents that have been used in ACE and applications that have been described for the resulting methods in clinical or pharmaceutical analysis. Binding agents that will be considered are antibodies, aptamers, lectins, serum proteins, carbohydrates, and enzymes. This review will also describe the various formats in which each type of binding agent has been used in $C E$, including both homogeneous and heterogeneous methods. Specific areas of applications that will be considered are CE-based immunoassays, glycoprotein/glycan separations, chiral separations, and biointeraction studies. The general principles and formats of ACE for each of these applications will be examined, along with the potential advantages or limitations of these methods.
\end{abstract}

Keywords: Affinity capillary electrophoresis, CE immunoassay, Chiral separations, Biointeraction studies, Enzyme assays

Published in Journal of Pharmaceutical and Biomedical Analysis 177 (2020) 112882 doi 10.1016/j.jpba.2019.112882

Copyright (c) 2019 Elsevier B.V. Used by permission.

Submitted 30 July 2019; revised 7 September 2019; accepted 10 September 2019; published 12 September 2019. 


\section{Contents}

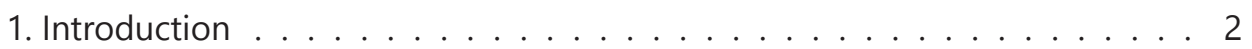

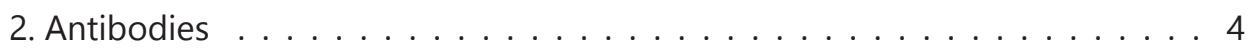

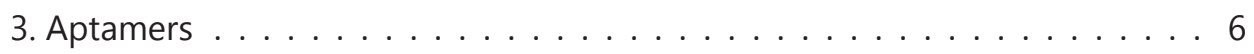

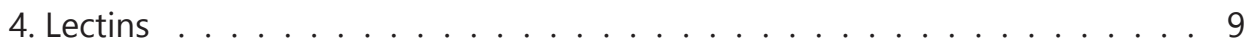

5. Serum proteins and related binding agents . . . . . . . . . . . 11

6. Carbohydrates . . . . . . . . . . . . . . . . . . . . 15

7. Enzymes . . . . . . . . . . . . . . . . . . . . 16

8. Conclusion . . . . . . . . . . . . . . . . . . . . . . 19

Acknowledgments . . . . . . . . . . . . . . . . . 20 20

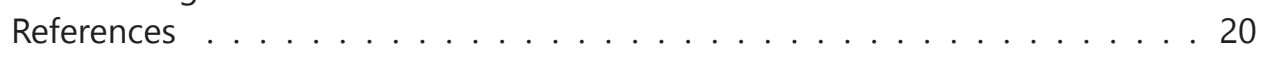

\section{Introduction}

Capillary electrophoresis (CE) is a separation technique in which a potential is applied across a capillary and used to separate chemicals based on their different rates of migration within the resulting electrical field [1-4]. CE is known to have several advantages when compared to traditional paper or gel-based electrophoresis. These advantages include the ability of CE to provide separations with high efficiencies, short analysis times, and small sample requirements [17]. These properties have made CE popular for several decades as an analytical tool for the separation and measurement of many types of compounds in biological, pharmaceutical, and clinical samples [2-8].

One way in which CE can be used is in combination with a biologically-related agent, or affinity ligand, that can bind and alter the migration of analytes within the CE system. The resulting technique is known as affinity capillary electrophoresis (ACE) [2,4-6,9-13]. This method has seen significant development and use since it was first described in the early 1990s. As is illustrated in Fig. 1, between 100 and 150 new papers per year have appeared on ACE over the last 15 years. An estimated 2650 papers or reviews have discussed this topic over the last 27 years.

Applications of ACE can be divided into two main categories: homogenous methods and heterogeneous methods [4,14]. In a homogenous method, the binding agent and analyte interact within a solution, as may occur within a sample or within a CE running buffer 


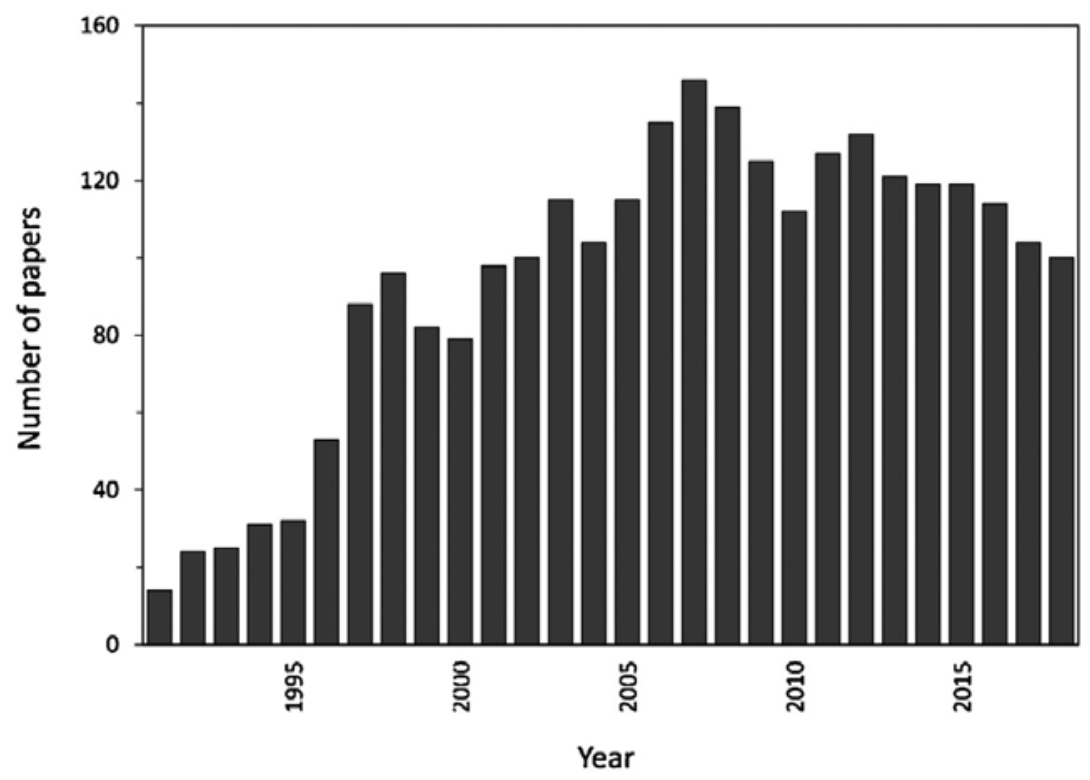

Fig. 1. Number of publications discussing affinity capillary electrophoresis that appeared per year between 1991 and 2018. This graph is based on a search that was conducted on the Web of Science in July 2019 for articles covering the topic "affinity capillary electrophoresis".

$[4,9,12]$. In a heterogeneous method, the binding agent is immobilized onto the inner surface of the CE system or onto a support that is used to aid in the capture or isolation of the analyte $[9,13,14]$. This second approach may also be viewed as a type of affinity chromatography that is combined with CE or that uses a binding agent in electrokinetic chromatography $[4,14-17]$.

This review will examine the types of binding agents that have been used in ACE and will discuss their applications in clinical and pharmaceutical analysis. These binding agents will include antibodies, aptamers, lectins, serum proteins, carbohydrates, and enzymes. Both homogeneous and heterogeneous ACE methods will be considered. This review will also describe the various formats in which each type of binding agent has been used in ACE. Areas that will be discussed will include CE-based immunoassays, glycoprotein/glycan separations, chiral separations, and biointeraction studies. The general principles of $A C E$, its various formats, and each of these applications will be presented, along with the potential advantages and limitations of each approach. 


\section{Antibodies}

An antibody is one type of binding agent that has been used in many types of CE methods [2,4,15-17]. An antibody, which is also known as an immunoglobulin, is a glycoprotein that is produced by the immune system in response to a foreign agent, or antigen. The structure of a typical antibody (e.g., immunoglobulin G, or $\lg G$ ) consists of two identical heavy chains and two identical light chains that are tied together by disulfide bonds. The lower stem area of an antibody is known as the $F_{c}$ region and is highly conserved from one type of antibody to the next in the same class. The two upper arms of an antibody are known as $\mathrm{F}_{\mathrm{ab}}$ regions and contain the binding regions that can interact with an antigen. The amino acid sequence in these binding regions can be highly variable between antibodies and is what makes it possible for a given antibody to bind specifically and strongly to a particular foreign agent $[15,16]$.

The use of antibodies as binding agents in CE gives a method that is often referred to as a CE immunoassay [13,17-19]. There are several types of formats available for these assays, with a competitive binding format being the most common $[17,19]$. This type of CE immunoassay is typically performed in a homogeneous mode, as is illustrated in Fig. 2(a) [17]. In this mode, the analyte, a fixed amount of a labeled analog of the analyte, and a limited amount of antibodies are mixed and allowed to incubate in solution. This mixture is then separated by CE and the amount of bound or non-bound labeled analog is detected. Due to competition between the analyte and labeled analog for the antibodies, the amount of analyte in the original sample will be related to both the amount of labeled analog that is bound to the antibodies and that remains free in solution $[17,19]$. An advantage of this approach is it can be used with either small or large targets and requires only small amounts of antibodies. Limitations of this method are that its limit of detection is often not as low as those of other CE immunoassays, and it cannot distinguish between multiple compounds that bind the same antibody [19].

Competitive CE immunoassays have been used with a variety of labels and to measure a large range of analytes [17-19]. Labels that have been used in this method have included fluorescent, chemiluminescent, and enzymatic tags $[17,19]$. Analytes that have been examined with competitive CE immunoassays have ranged from hormones 
(a) Competitive CE immunoassay

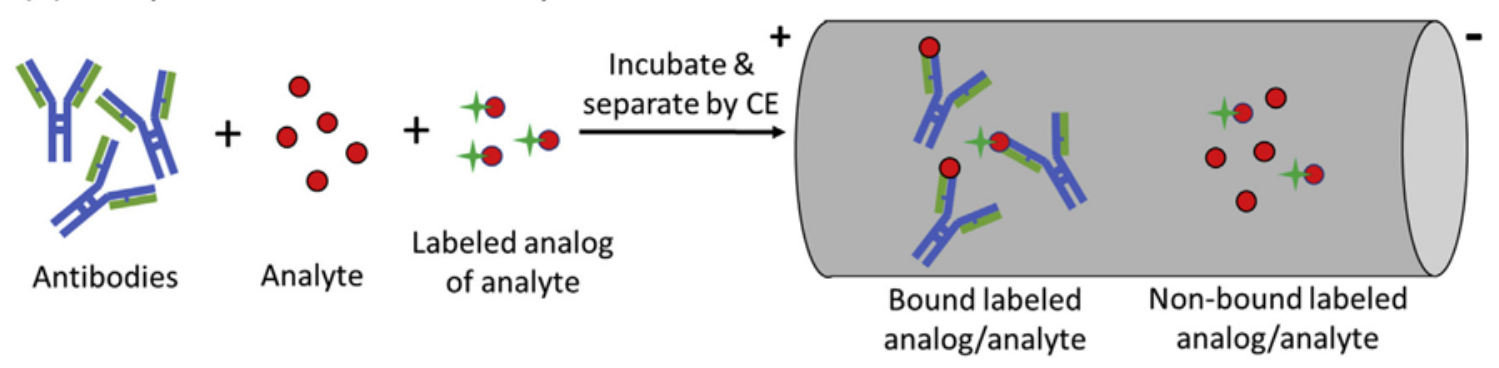

(b) Non-competitive CE immunoassay

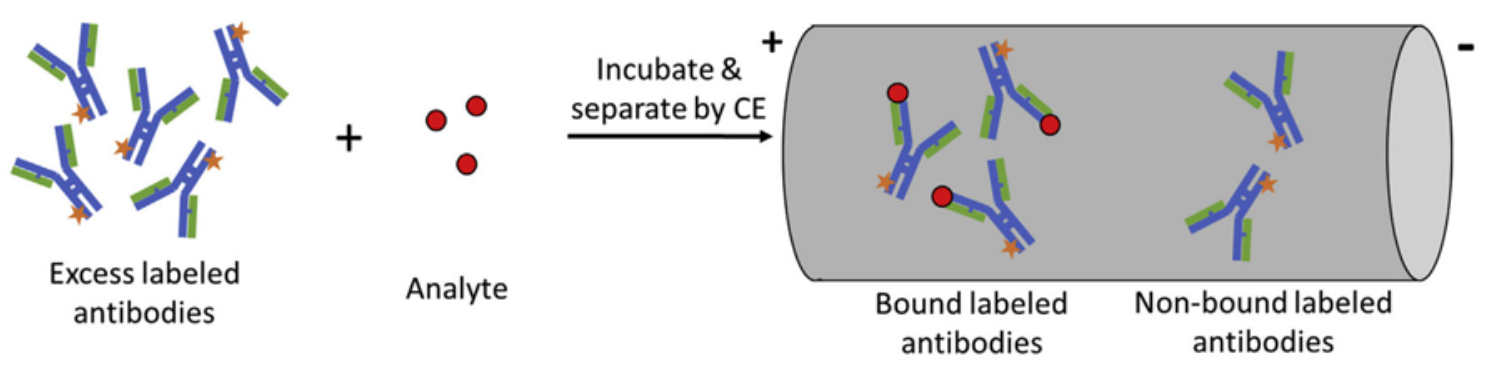

Fig. 2. General schemes for (a) a competitive CE immunoassay and (b) a non-competitive CE immunoassay [19].

and drugs to proteins and peptides [19]. Early examples of this assay used fluorescein as a label and laser-induced fluorescence detection to measure insulin [20] and to determine the binding constants of insulin with antibodies [21]. Other applications have used Cyanine 5 , green fluorescent protein, and horseradish peroxidase as labels to measure such targets as glucagon, thyroxine, alpha-fetoprotein, and insulin-like growth factor [19,22-24].

Non-competitive CE immunoassays can also be carried out in a homogeneous mode [17-19]. In this method, an excess of labeled antibodies, or a related binding agent, is mixed with the target analyte and allowed to form a labeled binding agent-analyte complex. CE is then used to separate the non-bound labeled binding agent from the binding agent-analyte complex, with the latter giving a signal that is related to the amount of analyte that was in the original sample [25]. This type of assay has been employed with many types of labels and analytes. For instance, non-competitive CE immunoassays have been utilized with tags such as fluorescein, horseradish peroxidase, and gold nanoparticles [19]. Analytes that have been examined with these 
methods have included hormones, immunoglobulins, tumor markers, and peptides [19,25-27]. A noncompetitive immunoassay with chemiluminescence detection has been used to measure the tumor marker CA15-3 in serum [25], and gold nanoparticles have been used with $C E$ and amplified chemiluminescent detection to measure carcinoembryonic antigen and IgG $[26,27]$. Some advantages of these methods are they tend to give lower detection limits and broader dynamic ranges than competitive CE assays. Potential limitations are the need for greater care in preparing the labeled agent in these assays, such as to avoid having a heterogeneous set of these labeled agents that may have a broad range of electrophoretic mobilities for their peaks in CE [19].

An alternative way in which a CE immunoassay can be carried out is in a heterogeneous format $[17,19,28]$. This approach is a variation on immunoaffinity chromatography, in which the antibodies or antibody-related binding agents are immobilized in a capillary to extract a target analyte or a group of related compounds from the sample, followed by their release and separation by CE $[19,28]$. Antibodies and antibody fragments have been immobilized within capillaries for the capture and analysis of compounds such as neurotrophins, cytokines, chemokines, and cyclosporine A [28-30]. Magnetic beads with immobilized antibodies against immunoglobulin E (IgE) have been used with CE and fluorescent labels to measure lgE in serum [31]. Magnetic beads have also been used in an immunoaffinity CE method with absorbance detection to examine AGP isoforms [32]. In addition, immobilized antibodies have been employed as stereoselective selectors in CE for chiral separations [33].

\section{Aptamers}

Aptamers have also been used in CE for the analysis of biological systems [13]. An aptamer is a binding agent consisting of single-stranded DNA or RNA (typical size, 10-100 nucleotides) or an oligopeptide that is used to selectively bind to a specific target $[34,35]$. These targets may be proteins, peptides, carbohydrates, or small molecules [34]. Aptamers based on oligonucleotides can be produced by a method known as the systematic evolution of ligands by exponential enrichment, or SELEX, as shown in Fig. 3 [35,36]. SELEX typically consists of a 


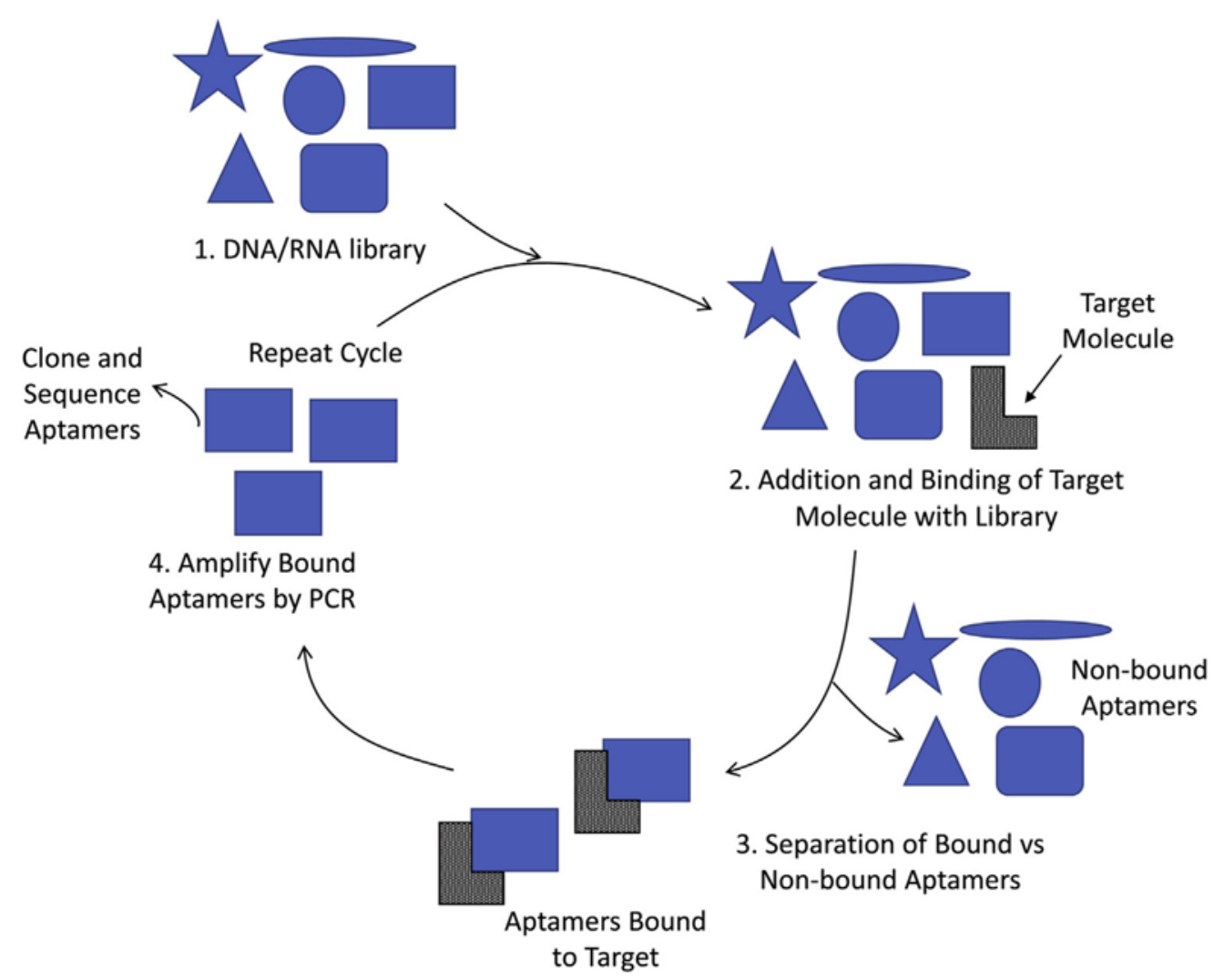

Fig. 3. General scheme for the systematic evolution of ligands by exponential enrichment (SELEX) method of producing aptamers. This figure is based on information provided in Refs. $[35,36]$.

four-step process. The first step involves the generation of a large random library of DNA or RNA oligonucleotides. Next, the target analyte is incubated with this library to allow for oligonucleotide-target binding. Once binding has occurred, the bound aptamers are isolated from the mixture. The non-bound aptamers are discarded while those that are bound to the target are amplified by using the polymerase chain reaction (PCR). The cycle is then repeated, as needed, with the amplified aptamers and with an increase in the stringency of conditions (e.g., by adjusting the temperature or $\mathrm{pH}$ ) to eventually obtain the sequence with the strongest or most ideal binding to the target [36].

Aptamers have several advantages when they are used as alternatives to antibodies in binding assays. Two advantages are the ability to prepare and screen aptamers, through methods such as SELEX, and the possibility of then preparing a given aptamer sequence through synthetic techniques. The smaller size of aptamers compared to 
antibodies can also be an advantage in some applications, along with the ability to use aptamers in solutions and under conditions in which antibodies may not be stable [37-39]. Possible limitations include the difficulty of generating an aptamer when no purified target is available and the rapid degradation that can occur for some types of aptamers (i.e., as is commonly seen when using RNA oligonucleotides) [36].

As was shown in the previous section for antibodies, aptamers can also be employed in CE in competitive or non-competitive binding assays $[37,39]$. Competitive binding assays in CE that employ aptamers are based on the competition between an analyte and fixed amount of a labeled analyte analog for sites on a limited amount of aptamers. CE is then used to separate the components of this mixture and to determine the amount of bound or non-bound labeled analog that is present, thus giving an indirect measure of the analyte that was present in the original sample. Fluorescent tags are often used for these assays due the ease with which aptamers can be modified with such labels. An example is an assay that was used to examine the competition and binding site of labeled vs unlabeled aptamers for IgE as their target [37].

Non-competitive binding assays in CE have also made use of aptamers. The scheme for such an assay is the same as shown in Fig. 2(b) but now uses labeled aptamers instead of antibodies [37,39]. For instance, a fluorescent-labeled DNA aptamer was used with this method to measure IgE and thrombin in standard samples or serum [37]. Aptamers conjugated to gold nanoparticles were employed in a CE-based chemiluminescence immunoassay for the analysis of thrombin in serum [40]. In addition, a CE assay with laser-induced fluorescence detection used aptamers to measure the protease human neutrophil elastase in serum [41].

A potential issue when using aptamers in CE is that an aptamertarget complex may be only moderately strong and dissociate during the separation process. A possible solution to this problem is to use a method known as nonequilibrium capillary electrophoresis of equilibrium mixtures (NECEEM) [42]. This method allows for the use of low affinity aptamers as probes for binding assays and analyte measurement. In this technique, a small plug of an equilibrium mixture (e.g., an aptamer and the target analyte) is injected into a capillary and a CE separation is carried out during which the aptamer-analyte 
complex is allowed to dissociate $[42,43]$. The resulting peaks or elution profiles for the free aptamer, the intact aptamer-target complex, and released target from the complex can be used to determine the amount of target that was present. This method has been used to measure thrombin based on a low-affinity, fluorescein-labeled aptamer for this protein [42].

\section{Lectins}

Lectins are a third group of binding agents that have been used in CE [44-55]. These are carbohydrate-binding proteins that are not produced by the immune system and that can be used to interact with compounds that contain glycans, such as glycopeptides, glycoproteins, and glycolipids [45]. The combined use of lectins with CE can produce an analytical method that is selective for a given type of glycan-containing target, as may be used to characterize the binding between carbohydrates and lectins, to identify glycans in a mixture, or to resolve some glycoforms of the target [45-55].

Lectins have been used in ACE with mobility shift assays to study the interactions of these binding agents with carbohydrates [46-48]. This type of assay is illustrated in Fig. 4. In this method, the lectin (or some other binding agent) is added at a known concentration to the running buffer. The analyte (e.g., a carbohydrate) is then injected into the buffer and CE system in the presence of various concentrations of the ligand, creating a shift in the observed mobility as the analyte binds to the lectin. The reverse process can also be performed in which the carbohydrate is instead added to the running buffer and the mobility of an injected lectin is monitored [9]. The equilibrium constant for the interaction of the lectin with the carbohydrate can be obtained by plotting the change in mobility or migration time as a function of the concentration of the lectin or carbohydrate in the mobile phase [9]. A number of studies have used this approach with fluorescence detection and derivatized carbohydrates to study the binding of these agents with lectins such as Ricinus communis agglutinin, Lens culinaris agglutinin, concanavalin A (Con A), wheat germ agglutinin, Tulipa gesneriana agglutinin, and Phaseolus vulgaris agglutinin [4649]. In one study, Ricinus communis agglutinin, peanut agglutinin, and 
(a) Analyte migration in absence of binding agent

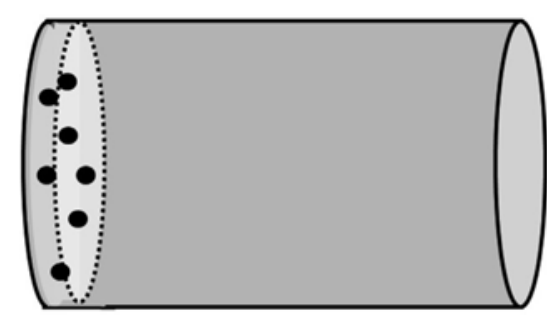

Analyte

Buffer

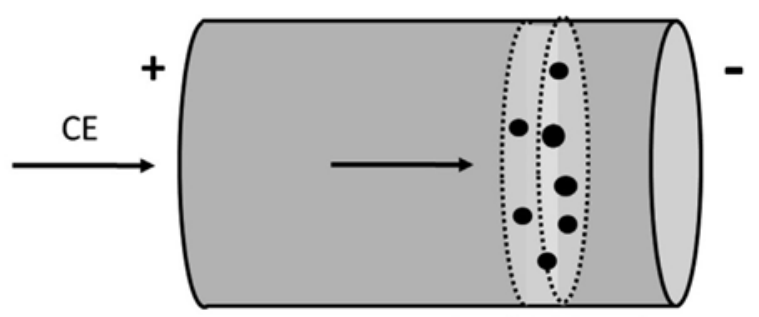

Analyte band

(b) Analyte migration in presence of binding agent

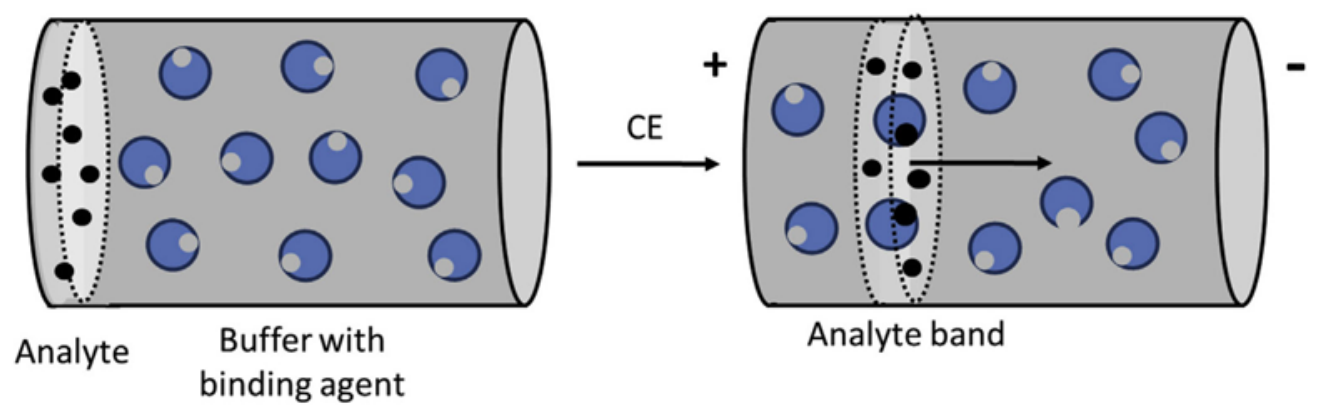

Fig. 4. General scheme for a mobility shift assay, showing the migration of an analyte in (a) the absence of any binding agent in the running buffer and (b) in the presence of the binding agent [14].

soy bean agglutinin were injected into a capillary filled with various concentrations of lactobionic acid to study the association between this agent and the given lectins [55].

Mobility shift assays have also been used with lectins to identify glycans in a mixture $[49,50]$. When there is a high level of binding present to a lectin, the peak of a target glycan can completely disappear. If the result is compared with an electropherogram with no lectins present, this information can be used to determine which peaks represent glycans with an affinity towards a particular lectin. In one study, six lectins were used as additives in a running buffer to identify terminal non-reducing monosaccharides and to differentiate galactose or fucose-linked isomers in a mixture of 24 milk oligosaccharides [49]. A partial filling technique has been used along with glycosidases to characterize $\mathrm{N}$-glycans of the therapeutic antibody rituximab [50]. Other work has used thermally-reversible nanogels with ACE to trap and immobilize a lectin within a plug of the nanogel [51,52]. This method has been used to profile the N-glycan composition of IgG [52]. 
Lectins have been used in ACE for the characterization of glycoproteins other than antibodies. For instance, a capillary that was partially filled with Con A has been used with ACE and absorbance detection to separate alpha ${ }_{1}$-acid glycoprotein (AGP) into fractions that differed in their content of bi-antennary glycans [53]. Fluorescent detection using a tagged form of AGP has also been used with CE and Con A or Aleuria Aurantia lectin to examine the glycoforms of AGP [54].

\section{Serum proteins and related binding agents}

Serum proteins have been used in a number of ways in $A C E$, including their use as chiral binding agents [56]. Two examples of these proteins are human serum albumin (HSA) and bovine serum albumin (BSA), which have been studied extensively due to their ability to bind

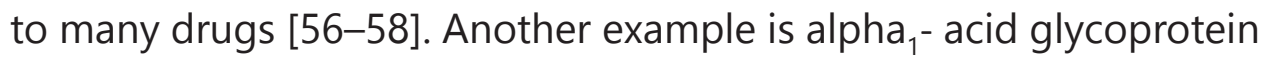
(AGP). AGP has a lower pl than HSA or BSA, also binds to a number of drugs, and has been often used as a stereoselective binding agent in ACE $[56,57]$. Another protein that has been used as a chiral binding agent in CE is the enzyme cellulase [59].

Many of these proteins can be added to the running buffer in ACE as binding agents or chiral recognition elements [60-63]. The result is essentially a mobility shift assay in which drugs or enantiomers that bind to these proteins will have a change in their apparent mobility and a separation from other solutes or chiral forms that have a different extent of interaction with the same protein [60-63]. The use of these proteins may be done either by filing the entire capillary with a buffer that contains these agents or by using a partial filling technique. A potential problem with the use of a protein in the entire buffer is that this may generate a large background signal at the detector [56,57,62-64]. The partial filling technique can overcome this disadvantage by creating conditions in which the protein solution is not present as the analyte enters the detection window; however, this approach can also be more complex to perform and optimize than the use of a protein solution throughout the CE system [56,57,62,63].

Both AGP and albumins have been used in homogeneous methods for binding studies and chiral separations in ACE [64-67]. For instance, ACE has been used to estimate the binding constants between the enantiomers of disopyramide and remoxipride with AGP [64]. The use of 
BSA as a buffer additive for the separation of chiral drugs like ephedrine has been examined, including the effects of varying the $\mathrm{pH}$, buffer concentration, and BSA concentration on the resolution of such methods [65]. ACE has further been used to study the conformational change of soluble HSA as it binds with the drug mexiletine [66] and the use of HSA as a buffer additive to separate omeprazole enantiomers [67]. In addition, BSA, HSA, and AGP have been used in ACE for the enantiomeric separation of drugs and solutes such as tryptophan, warfarin, leucovorin, temazepam, oxazepam, benzoin, cyclophosphamide, pentobarbital, hexobarbital, ifosfamide, metoprolol, oxprenolol, and alprenolol [68].

Heterogeneous methods using immobilized serum proteins in CE have been reported in some studies [69-76]. Immobilization has been carried out by placing proteins within a gel, coupling the proteins onto a support that is packed into a capillary, and or coating the proteins onto the capillary wall [70-76]. For instance, BSA has been immobilized in a gel for the chiral separation of D- and L-tryptophan [70]. BSA attached to silica monoliths has been used in CE to separate D- and L-tryptophan [73], and a mixture of HSA and cellulase has been immobilized in an organic monolith and used in CE to expand the range of chiral agents that can be resolved over that which can be obtained by either protein alone [74]. BSA coated on polystyrene nanoparticles has been used to separate D- and L-tryptophan [75], and a dynamic coating of HSA in CE has been employed for the separation of $R$ - and S-warfarin [76].

Another application of ACE with serum proteins is in studies that examine the binding of drugs and other solutes with these agents, as can be used to aid in the characterization of drug pharmacokinetics and pharmacodynamics [14]. Many methods have been developed that can examine solute-protein interactions that are relatively fast compared to the time scale of a CE separation. These methods include mobility shift assays, as discussed in the previous section, and vacancy techniques $[14,63,77-79]$. Mobility shift assays can be conducted in a similar manner to that described in Section 4 and are based on the observed change in migration time for a drug or solute in the presence of buffers that contain known concentrations of a binding agent [62]. For instance, the competitive binding of ibuprofen and salicylic acid with HSA was investigated by a mobility shift assay [80], and ACE was used to examine the binding of retinol and retinoic acid with HSA and BSA as buffer additives [81]. 
In a vacancy technique known as the equilibrium saturation method, the capillary is filled with a buffer that contains both the analyte and binding agent (e.g., a protein) at equilibrium, as shown in Fig. 5(a) [14]. The concentration of one of these agents is fixed while the other is varied while injections are made of only buffer onto the

(a) Equilibrium saturation method

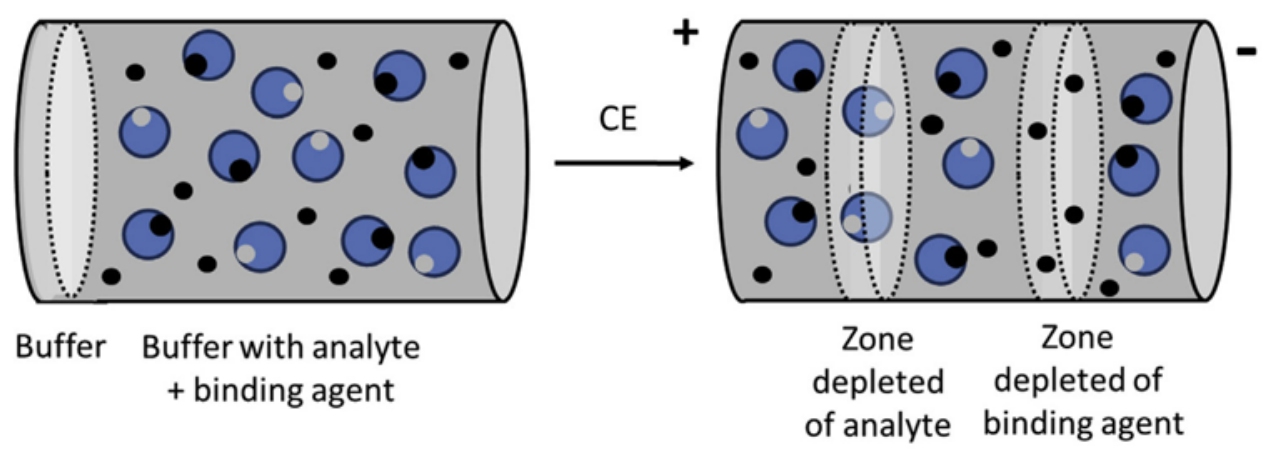

(b) Hummel-Dreyer method

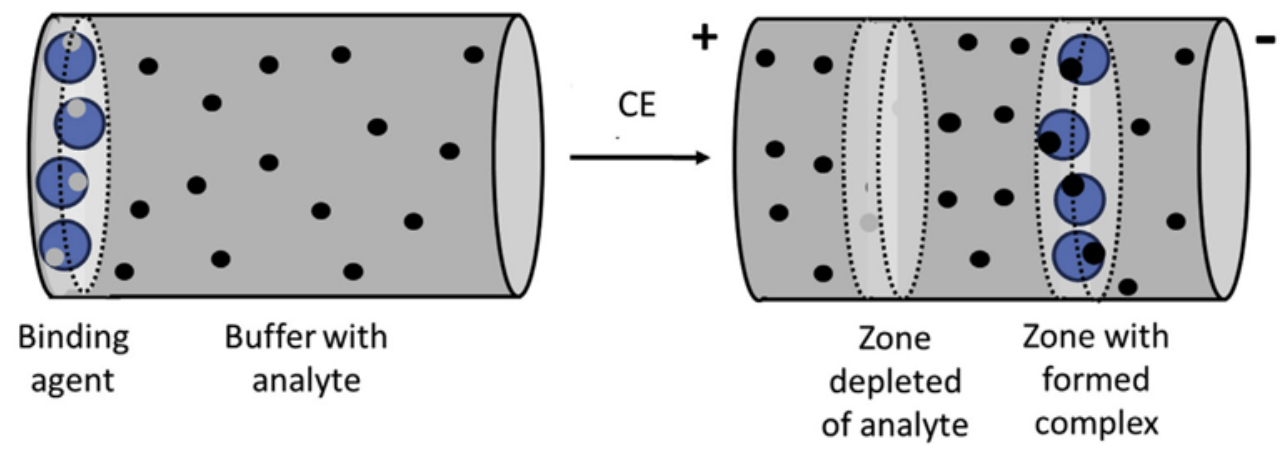

(c) Frontal analysis
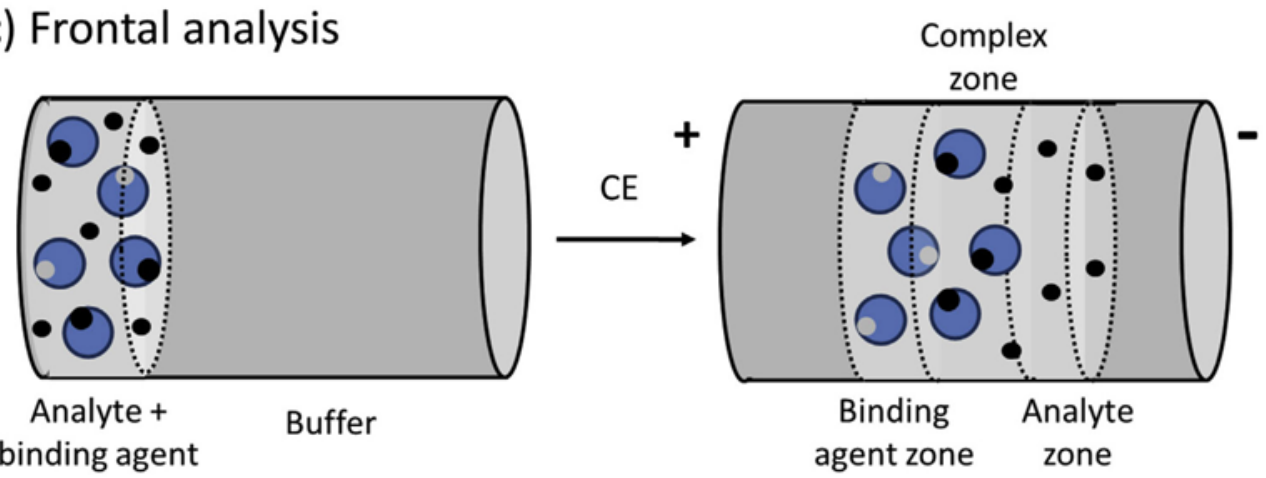

Fig. 5. General schemes for the (a) equilibrium saturation method, (b) HummelDreyer method and (c) frontal analysis method for conducting binding studies by ACE [14]. 
CE system. Under suitable detection conditions, this situation can lead to two vacancy peaks in the electropherogram that are produced by a local change in analyte and binding agent content of the running buffer as the injected plug passes through the capillary. The results can be used to determine the amount of analyte that is present in the running buffer in a free vs bound form [14,63,82]. This method has been compared with other ACE methods when used to examine the binding of warfarin with BSA [82]. This approach has also been employed in examining the competition of warfarin with furosemide and phenylbutazone in the presence of BSA [83].

The Hummel-Dreyer method is a second type of vacancy technique that can be used in ACE for binding studies. This method is illustrated in Fig. 5(b). The analyte is first placed at various known concentrations into the running buffer, resulting in a background signal that is proportional to the level of analyte that is present $[14,84,85]$. A small amount of binding agent is then injected into the capillary. Under appropriate detection conditions, a negative peak can be produced from the reduced local concentration of the analyte as it forms a complex with the injected binding agent. The area of this negative peak can be used to estimate the concentration of the bound form of the analyte. This method has been used in ACE to characterize the binding of BSA with salicylic acid [84]. Binding by the platinum-containing drugs cisplatin and oxaliplatin with HSA and transferrin has also been characterized by this approach [85].

Frontal analysis is a method that can be used in ACE binding studies when a system has slow kinetics compared to the time needed for a CE separation [14,86-88]. This approach is shown in Fig. 5(c). In frontal analysis by $\mathrm{CE}_{\mathrm{B}}$ a relatively large volume of an analyte/binding agent mixture that is at equilibrium is injected into the $C E$ system $[56,57,62,63,78,86]$. If the analyte and binding agent/complex have a measurable difference in their mobilities, the injected plug will produce a series of zones by the time it reaches the detector. The free form of the analyte and the analyte-ligand complex will correspond to two of the zones in the electropherogram (Note: the zone for the non-bound ligand may overlap with that of the complex, as can occur in drug-protein binding studies). The response over the free analyte zone can be used with an external calibration curve to determine the concentration of the analyte in this form. This technique has been employed in a number of reports to examine the binding 
by drugs with serum proteins [89-91]. For instance, this method has been used with mass spectrometry to investigate the interactions of propranolol, pindolol, warfarin, oxprenolol, alprenolol, salicylic acid, carbamazepine, and diclofenac with AGP and BSA [89], as well as the binding of loureirin B with HSA [90] and the interactions of sulfonylurea drugs with normal and glycated HSA [91]. One advantage of this method is it is less sensitive to variations in the applied voltage than methods that measure changes in mobility or migration rates. However, this method does tend to require the presence of stronger interactions than other common techniques that are used in ACE for binding studies [14,86-88].

\section{Carbohydrates}

Carbohydrates are yet another class of binding agents that can be used in ACE [92]. The use and analysis of glycans in ACE was discussed earlier in Section 4. Another common group of carbohydrates that have been used in ACE are the cyclodextrins (CDs). CDs are cyclic polymers of glucose, in which each subunit of glucose is joined to the next through an alpha-1,4-glycosidic bond [92,93]. CDs come in various sizes; these include alpha-, beta-, and gamma-CD, which contain five, six and seven subunits, respectively [92]. These polymers have a toroid shape with hydroxyl groups arranged on both the ends. This structure and arrangement of groups allows CDs to bind non-polar compounds while still remaining soluble in water [92]. These properties have made CDs useful in the pharmaceutical industry as agents that can be used to solubilize and deliver drugs [94,95]. The chiral arrangement of the hydroxyl groups on CDs and the ability of these agents to undergo multiple simultaneous interactions with a solute have also made CDs valuable as chiral recognition elements for CE [96].

Many applications of CDs in CE have involved their use as buffer additives [92]. In this mode, the CD in the running buffer is used to bind an injected analyte and to alter its apparent mobility vs other sample components [92]. This approach has been used to separate and analyze the antihistamine loratadine and one of its major metabolites, desloratadine, in urine samples [97]. The same format can be used for chiral separations [98]. A recent report based on this approach used it to separate a mixture of eleven psychoactive chiral 
amines [99]. Other applications have included the chiral analysis of pharmaceuticals such as levornidazole [100] or verapamil [101]. This method has also been utilized to measure various L-amino acids in biological matrices [102]. In addition, CE has been used to determine the binding constants of CDs with solutes such as drugs targeting neurodegenerative diseases or pharmaceuticals that are used to treat obesity $[103,104]$.

\section{Enzymes}

Enzymes are another set of biological agents that have been used in CE [105-114]. Enzymes are biological molecules that act as catalysts for chemical reactions in living systems. One application in CE that has already been mentioned in Section 5 is use of the enzyme cellulase as a stereoselective binding agent for chiral separations $[59,74]$. However, CE has also been used in a number of studies to characterize enzyme-substrate interactions and kinetics [105-112]. This has been done by using pre-capillary assays, in-capillary enzyme assays or immobilized enzyme reactors (IMERs) [105].

In a pre-capillary assay, the enzyme and substrate are mixed and incubated with the co-factors and other reaction components for a given period of time [105]. The reaction is then quenched by freezing or by adding perchloric acid or hydrochloric acid [106-109]. The mixture is injected onto a CE system to separate the reaction product ( s) and substrates. Advantages of pre-capillary enzyme assays in $\mathrm{CE}$ are their high sensitivity, good reproducibility, and ease of control. However, an enzymatic reaction must be fast to be used in this method. Even though only a small volume of the reaction Fig. 6. General scheme for an in-capillary enzyme assay conducted by CE $[105,112]$. mixture is injected, this format for an enzyme assay requires much more reagent and sample than an in-capillary method because the reaction components are combined and incubated before they are used in CE $[110,113,114]$.

Several applications of pre-capillary enzyme assays have been reported [109-114]. This method has been used to examine the activity of carbonic anhydrase and its inhibition in the presence of furosemide [109]. A pre-capillary assay was used to determine and compare the affinities and turnover rates of camel and bovine chymosin with 
(a) Apply incubation buffer, enzyme \& substrate

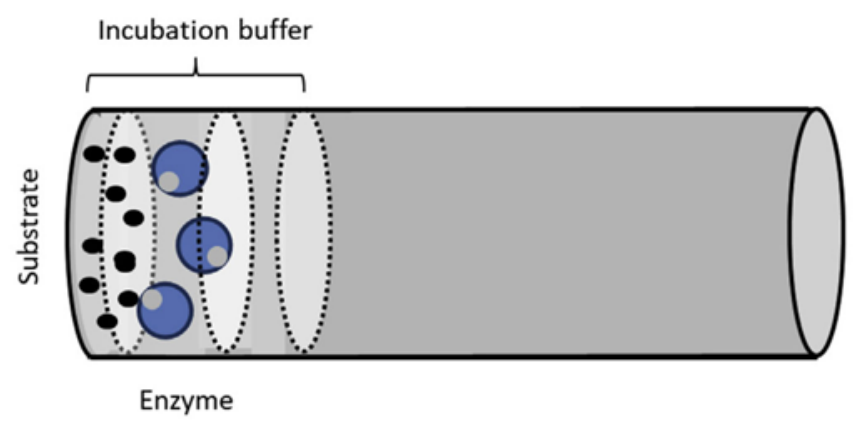

(b) Allow reagents to mix and form products

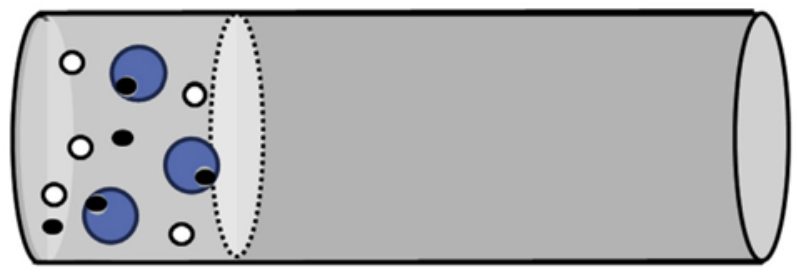

(b) Separate substrate, enzyme \& product by CE

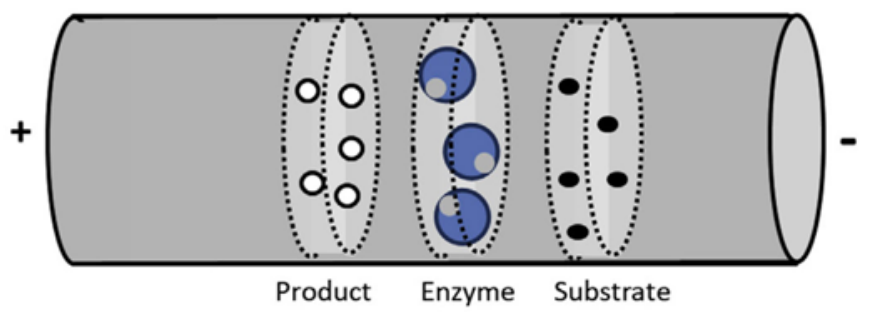

Fig. 6. General scheme for an in-capillary enzyme assay conducted by CE $[105,112]$.

regards to the hydrolysis of bovine kappa-casein [110] and to examine the action of myrosinase on natural and synthetic glucosinolate substrates [111]. Pre-capillary enzyme assays have also been used to screen neuraminidase inhibitors from Phascolosma esculenta [112], polyoxometalates as alpha-glucosidase inhibitors [114], and furosemide as a carbonic anhydrase inhibitor [109].

The use of an in-capillary enzyme assay involves a system in which enzyme/substrate mixing occurs in the capillary, as shown in Fig. 6 [105]. This means the capillary is used for both separation and as a micro-reactor for the enzymatic reaction [112]. The advantages of this format are that all major steps (including the enzyme reaction, mixing, separation, and detection) occur within the capillary. This makes this 
approach easy to automate and to use in miniaturized devices. Furthermore, only small volumes of the enzymes, substrates and chemicals are used and no quenching is required [112].

One way in-capillary enzyme assays can be conducted is by using electrophoretically mediated microanalysis (EMMA) [115-122]. In EMMA, the reactants are mixed and the enzymatic reaction is triggered by utilizing the difference in electrophoretic mobilities of the reactants when an electric field is applied [112,115-119]. In the continuous engagement (or long contact) mode of this method, the entire capillary is filled with one of the reactants; either the enzyme or the substrate is then introduced as a small zone or as a moving boundary [116]. Moving boundary EMMA has been used to study the enzyme kinetics of microsomal leucine aminopeptidase during the hydrolysis of L-leucine-p-nitroanilide [116]. The zonal mode of EMMA has been utilized to examine the catalytic action of glucose-6-phosphate dehydrogenase on glucose- 6-phosphate [115]. A partial filling mode of EMMA has been used to determine the enzyme kinetics for conversion of $S$ - and $R$-fluoxetine by cytochrome 2D6 [118] and has been combined with a separation using highly sulfated beta-CD to examine the action of cytochrome p450 enzymes on $R$ - and $S$-verapamil [119]. EMMA has further been employed as a tool to examine potential aromatase inhibitors in traditional Chinese medicine [120], to examine the action of cytochrome p450 enzymes on ketamine [121], and to screen protein kinase inhibitors [123].

It is also possible to mix the reactants in a CE-based enzyme assay by using alternative approaches. Examples are the use of longitudinal diffusion or transverse diffusion at the capillary inlet $[124,125]$. This type of approach has been utilized to examine the hydrolysis of potential fluorogenic substrates by human neutrophil elastase [126]. Mixing based on diffusion in a nanoliter-capillary reactor has been employed to examine the stereoselective metabolism of ketamine by cytochrome p450 [127].

An IMER is another tool that can be employed in CE to study enzyme reactions [128-139]. The use of an immobilized enzyme has the advantage of allowing the same enzyme preparation to be used for many studies, thus reducing the overall cost and improving reproducibility. However, care must be taken so that the immobilization process does not significantly alter the enzyme's activity. Immobilization may be based on physical adsorption, covalent attachment, 
or encapsulation [129]. The use of CE with an IMER has been used to study the hydrolytic action of beta-glucosidase on $p$-nitrophenyl betaD-glucopyranoside to form nitroaniline [130] and the action of betasecretase on an amyloid $\beta / A 4$ protein precursor [131]. An IMER was used to study the enzyme kinetics of trypsin and to screen for its inhibitors in natural products [137]. An IMER for CE that was produced through layer-by-layer electrostatic assembly was used to characterize glucose-6-phosphate dehydrogenase inhibitors [138] and to screen tyrosinase inhibitors [139].

\section{Conclusion}

This review examined several general types of binding agents that have been used in ACE and related methods for clinical and pharmaceutical applications. It was shown how a broad range of biological binding agents have already been used in such methods. These have ranged from specific agents, such as antibodies and aptamers, to more general ones, such as lectins, serum proteins, and cyclodextrins. Enzymes and their interactions with substrates or inhibitors have also been employed in CE. Areas in which these binding agents have been used include CE immunoassays, the analysis of glycoproteins or glycans, chiral separations, and biointeraction studies.

It was shown how these binding agents can be utilized with CE in a variety of formats and in both homogeneous and heterogeneous methods. Examples of formats that were discussed were competitive and non-competitive binding assays, as have been used with antibodies or aptamers, and mobility shift assays, as have been employed with agents such as lectins, serum proteins, and cyclodextrins. The use of immobilized binding agents in CE was also discussed. In addition, a variety of techniques by which ACE can be used to study biological interactions were examined. These included mobility shift assays, vacancy techniques, frontal analysis, and pre-capillary or in-capillary enzyme assays.

Given the range of formats and binding agents that can be used in $C E$, it is expected that applications for this method will continue to grow. Further developments are also expected in the types of binding agents that can be used in this method, the formats by which they can be employed, and coupling of these techniques with other methods, 
such as mass spectrometry, affinity supports, or IMERs. These developments should result in even more uses for ACE and related methods in the future in biomedical fields such as clinical testing, pharmaceutical analysis, glycomics, and the study of biological interactions.

Acknowledgements - This work was supported, in part, by the National Institutes of Health (NIH) under grants R01 DK069629 and R01 GM044931.

\section{References}

[1] C.F. Poole (Ed.), Capillary Electromigration Separation Methods, Elsevier, Amsterdam, 2018.

[2] T.M. Phillips, H. Kalish (Eds.), Clinical Applications of Capillary Electrophoresis, Humana Press, Totowa, 2013.

[3] J.S. Torano, R. Ramautar, G. de Jong, Advances in capillary electrophoresis for the life sciences, J. Chromatogr. B 1118-1119 (2019) 116-136.

[4] C. Zhang, D.S. Hage, Clinical chemistry applications of capillary electromigration methods, in: C.F. Poole (Ed.), Capillary Electromigration Separation Methods, Elsevier, Amsterdam, 2018, pp. 423-452.

[5] S. Stepanova, V. Kasicka, Recent applications of capillary electromigration methods to separation and analysis of proteins, Anal. Chim. Acta 933 (2016) 23-42.

[6] P. Dubsky, M. Dvorak, M. Ansorge, Affinity capillary electrophoresis: the theory of electromigration, Anal. Bioanal. Chem. 408 (2016) 8623-8641.

[7] D.S. Hage, An overview of CE in clinical analysis, in: T.M. Phillips (Ed.), Clinical Applications of Capillary Electrophoresis, Humana Press, New York, 2019, pp. 3-11.

[8] H. Nevidalova, L. Michalcova, Z. Glatz, Capillary electrophoresis-based approaches for the study of affinity interactions combined with various sensitive and nontraditional detection techniques, Electrophoresis 40 (2019) 625-642.

[9] N.H.H. Heegaard, S. Nilsson, N.A. Guzman, Affinity capillary electrophoresis: important application areas and some recent developments, J. Chromatogr. B 715 (1998) 29-54.

[10] K. Shimura, K. Kasai, Affinity capillary electrophoresis: a sensitive tool for the study of molecular interactions and its use in microscale analyses, Anal. Biochem. 251 (1997) 1-16.

[11] H.M. Albishri, S. El Deeb, N. AlGarabli, R. AlAstal, H.A. Alhazmi, M. Nachbar, D.A. El-Hady, H. Watzig, Recent advances in affinity capillary electrophoresis for binding studies, Bioanalysis 6 (2014) 3369-3392.

[12] N.H.H. Heegaard, C. Schou, Affinity ligands in capillary electrophoresis, in: D.S. Hage (Ed.), Handbook of Affinity Chromatography, 2nd ed., CRC Press, Boca Raton, 2005, pp. 699-736. 
[13] F. Yu, Q. Zhao, D. Zhang, Z. Yuan, H. Wang, Affinity interactions by capillary electrophoresis: binding, separation, detection, Anal. Chem. 91 (2019) 372-387.

[14] D.S. Hage, S.A. Tweed, Recent advances in chromatographic and electrophoretic methods for the study of drug-protein interactions, J. Chromatogr. B 699 (1997) 499-528.

[15] D.S. Hage, A.C. Moser, Chromatographic immunoassays, in: D.S. Hage (Ed.), Handbook of Affinity Chromatography, 2nd ed., CRC Press, Boca Raton, 2005, pp. 789-836.

[16] A.C. Moser, D.S. Hage, Immunoaffinity chromatography: an introduction to applications and recent developments, Bioanalysis 2 (2010) 769-790.

[17] A.C. Moser, D.S. Hage, Capillary electrophoresis-based immunoassays: principles and quantitative applications, Electrophoresis 29 (2008) 3279-3295.

[18] D.S. Hage, Immunoassays, Anal. Chem. 67 (1995) 455R-462R.

[19] A.C. Moser, C.W. Willicott, D.S. Hage, Clinical applications of capillary electrophoresis-based immunoassays, Electrophoresis 35 (2014) 937-955.

[20] L. Tao, R.T. Kennedy, On-line competitive immunoassay for insulin based on capillary electrophoresis with laser-induced fluorescence detection, Anal. Chem. 68 (1996) 3899-3906.

[21] L. Tao, R.T. Kennedy, Measurement of antibody-antigen dissociation constants using fast capillary electrophoresis with laser-induced fluorescence detection, Electrophoresis 18 (1997) 112-117.

[22] C. Guillo, M.G. Roper, Two-color electrophoretic immunoassay for simultaneous measurement of insulin and glucagon content in islets of Langerhans, Electrophoresis 29 (2008) 410-416.

[23] X.M. Li, F. Zhang, S.S. Zhang, Capillary electrophoresis enzyme immunoassay for alpha-fetoprotein and thyroxine in human serum with electrochemical detection, J. Sep. Sci. 31 (2008) 336-340.

[24] Q. Pan, S. Hong, X. Zhu, M. Zhao, L.P. Lee, On-line electrophoretic sample clean-up for sensitive and reproducible _CE immunoassay, Lab Chip 12 (2012) 932-938.

[25] Y.M. Liu, Y.L. Zheng, J.T. Cao, Y.H. Chen, F.R. Li, Sensitive detection of tumor marker CA15-3 in human serum by capillary electrophoretic immunoassay with chemiluminescence detection, J. Sep. Sci. 31 (2008) 1151-1155.

[26] Y.M. Liu, L. Mei, L.J. Liu, L.F. Peng, Y.H. Chen, S.W. Ren, Sensitive chemiluminescence immunoassay by capillary electrophoresis with gold nanoparticles, Anal. Chem. 83 (2011) 1137-1143.

[27] J. Jiang, S. Zhao, Y. Huang, G. Qin, F. Ye, Highly sensitive immunoassay of carcinoembryonic antigen by capillary electrophoresis with gold nanoparticles amplified chemiluminescence detection, J. Chromatogr. A 1282 (2013) 161-166.

[28] T.M. Phillips, J.J. Chmielinska, Immunoaffinity capillary electrophoretic analysis of cyclosporin in tears, Biomed. Chromatogr. 8 (1994) 242-246. 
[29] T.M. Phillips, B.F. Dickens, Analysis of recombinant cytokines in human body fluids by immunoaffinity capillary electrophoresis, Electrophoresis 19 (1998) 2991-2996.

[30] H. Kalish, T.M. Phillips, Analysis of neurotrophins in human serum by immunoaffinity capillary electrophoresis (ICE) following traumatic head injury, J. Chromatogr. B 878 (2010) 194-200.

[31] H.X. Chen, J.M. Busnel, G. Peltre, X.X. Zhang, H.H. Girault, Magnetic beads based immunoaffinity capillary electrophoresis of total serum IgE with laserinduced fluorescence detection, Anal. Chem. 80 (2008) 9583-9588.

[32] G. Morales-Cid, J.C. Diez-Masa, M. De Frutos, On-line immunoaffinity capillary electrophoresis based on magnetic beads for the determination of alpha-1 acid glycoprotein isoforms profile to facilitate its use as biomarker, Anal. Chim. Acta 773 (2013) 89-96.

[33] N.M. Grubor, D.W. Armstrong, R. Jankowiak, Flow-through partialfilling affinity capillary electrophoresis using a crossreactive antibody for enantiomeric separations, Electrophoresis 27 (2006) 1078-1083.

[34] A.D. Ellington, J.W. Szostak, In vitro selection of RNA molecules that bind specific ligands, Nature 346 (1990) 818-822.

[35] S.J. Klug, M. Famulok, All you wanted to know about SELEX, Mol. Biol. Rep. (1994) 97-107.

[36] Y.X. Wu, Y.J. Kwon, Aptamers: the "evolution" of SELEX, Methods 106 (2016) 21-28.

[37] I. German, D.D. Buchanan, R.T. Kennedy, Aptamers as ligands in affinity probe capillary electrophoresis, Anal. Chem. 70 (1998) 4540-4545.

[38] S. Klussmann (Ed.), The Aptamer Handbook: Functional Oligonucleotides and Their Applications, Wiley, Weinheim, Germany, 2006.

[39] N.H.H. Heegaard, R.T. Kennedy, Identification, quantitation, and characterization of biomolecules by capillary electrophoretic analysis of binding interactions, Electrophoresis 20 (1999) 3122-3133.

[40] Y. Liu, Y. Liu, M. Zhou, K. Huang, J. Cao, H. Wang, Y. Chen, Chemiluminescence detection of protein in capillary electrophoresis using aptamer-functionalized gold nanoparticles as biosensing platform, J. Chromatogr. A 1340 (2014) 128-133.

[41] Y. Bai, H. Wang, Q. Zhao, Detection of human neutrophil elastase by aptamer affinity capillary electrophoresis coupled with laser-induced fluorescence using specified site fluorescently labeled aptamer, Anal. Bioanal. Chem. 409 (2017) 6843-6849.

[42] M. Berezovski, R. Nutiu, Y. Li, S.N. Krylov, Affinity analysis of a proteinaptamer complex using nonequilibrium capillary electrophoresis of equilibrium mixtures, Anal. Chem. 75 (2003) 1382-1386.

[43] M. Blind, M. Blank, Aptamer selection technology and recent advances, Mol. Ther. Nucleic Acids 4 (2015) e223.

[44] E.J.M. Van Damme, Handbook of Plant Lectins: Properties and Biomedical Applications, John Wiley, Chichester, 1998. 
[45] Y. Kobayashi, H. Tateno, H. Ogawa, K. Yamamoto, J. Hirabayashi, Comprehensive list of lectins: origins, natures, and carbohydrate specificities, in: J. Hirabayashi (Ed.), Lectins, Springer, New York, 2014, pp. 555-577.

[46] A. Taga, K. Uegaki, Y. Yabusako, A. Kitano, S. Honda, Simultaneous determination of the association constants of oligosaccharides to a lectin by capillary electrophoresis, J. Chromatogr. A 837 (1999) 221-229.

[47] M. Hong, A. Cassely, Y. Mechref, M.V. Novotny, Sugar-lectin interactions investigated through affinity capillary electrophoresis, J. Chromatogr. B 752 (2001) 207-216.

[48] K. Nakajima, Y. Oda, M. Kinoshita, K. Kakehi, Capillary affinity electrophoresis for the screening of post-translational modification of proteins with carbohydrates, J. Proteome Res. 2 (2003) 81-88.

[49] K. Nakajima, M. Kinoshita, N. Matsushita, T. Urashima, M. Suzuki, A. Suzuki, K. Kakehi, Capillary affinity electrophoresis using lectins for the analysis of milk oligosaccharide structure and its application to bovine colostrum oligosaccharides, Anal. Biochem. 348 (2006) 105-114.

[50] Y. Yagi, S. Yamamoto, K. Kakehi, T. Hayakawa, Y. Ohyama, S. Suzuki, Application of partial-filling capillary electrophoresis using lectins and glycosidases for the characterization of oligosaccharides in a therapeutic antibody, Electrophoresis 32 (2011) 2979-2985.

[51] S.A. Archer-Hartmann, L.M. Sargent, D.T. Lowry, L.A. Holland, Microscale exoglycosidase processing and lectin capture of glycans with phospholipid assisted capillary electrophoresis separations, Anal. Chem. 83 (2011) 2740-2747.

[52] G. Lu, L.A. Holland, Profiling the N-glycan composition of IgG with lectins and Capillary nanogel electrophoresis, Anal. Chem. 91 (2019) 1375-1383.

[53] M. Bergstrom, M. Nilsson, R. Isaksson, I. Ryden, P. Pahlsson, S. Ohlson, Lectin affinity capillary electrophoresis in glycoform analysis applying the partial filling technique, J. Chromatogr. B 809 (2004) 323-329.

[54] K. Shimura, M. Tamura, T. Toda, S. Yazawa, K. Kasai, Quantitative evaluation of lectin-reactive glycoforms of _1-acid glycoprotein using lectin affinity capillary electrophoresis with fluorescence detection, Electrophoresis 32 (2011) 2188-2193.

[55] S. Honda, A. Taga, K. Suzuki, S. Suzuki, K. Kakehi, Determination of the association constant of monovalent mode protein-sugar interaction by capillary zone electrophoresis, J. Chromatogr. A 597 (1992) 377-382.

[56] D.K. Lloyd, A.F. Aubry, E. De Lorenzi, Selectivity in capillary electrophoresis: the use of proteins, J. Chromatogr. A 792 (1997) 349-369.

[57] D.S. Hage, Chiral separations in capillary electrophoresis using proteins as stereoselective binding agents, Electrophoresis 18 (1997) 2311-2321.

[58] Z.D. Zhivkova, Studies on drug-human serum albumin binding: the current state of the matter, Curr. Pharm. Des. 21 (2015) 1817-1830.

[59] M. Nilsson, V. Harang, M. Bergstrom, S. Ohlson, R. Isaksson, G. Johansson, Determination of protein-ligand affinity constants from direct migration time in capillary electrophoresis, Electrophoresis 25 (2004) 1829-1836. 
[60] S.A.C. Wren, R.C. Rowe, Theoretical aspects of chiral separation in capillary electrophoresis. I. Initial evaluation of a model, J. Chromatogr. A 603 (1992) 235-241.

[61] S.A.C. Wren, R.C. Rowe, Theoretical aspects of chiral separation in capillary electrophoresis. II. The role of organic solvent, J. Chromatogr. A 609 (1992) 363-367.

[62] Z. Chen, S.G. Weber, Determination of binding constants by affinity capillary electrophoresis, electrospray ionization mass spectrometry and phasedistribution methods, Trends Analyt. Chem. 27 (2008) 738-748.

[63] K.L. Rundlett, D.W. Armstrong, Methods for the determination of binding constants by capillary electrophoresis, Electrophoresis 22 (2001) 1419-1427.

[64] A. Amini, D. Westerlund, Evaluation of association constants between drug enantiomers and human _1-acid glycoprotein by applying a partialfilling technique in affinity capillary electrophoresis, Anal. Chem. 70 (1998) $1425-1430$.

[65] N. Ye, X. Gu, G. Luo, Chiral separation of ephedrine isomers by capillary electrophoresis using bovine serum albumin as a buffer additive, J. Chromatogr. Sci. 45 (2007) 246-250.

[66] H. Xu, X.D. Yu, H.Y. Chen, Analysis of conformational change of human serum albumin using chiral capillary electrophoresis, J. Chromatogr. A 1055 (2004) 209-214.

[67] Y. Xu, T. Hong, X. Chen, Y. Ji, Affinity capillary electrophoresis and fluorescence spectroscopy for studying enantioselective interactions between omeprazole enantiomer and human serum albumin, Electrophoresis 38 (2017) 1366-1373.

[68] J. Haginaka, Enantiomer separation of drugs by capillary electrophoresis using proteins as chiral selectors, J. Chromatogr. A 875 (2000) 235-254.

[69] M.C. Millot, Separation of drug enantiomers by liquid chromatography and capillary electrophoresis, using immobilized proteins as chiral selectors, J. Chromatogr. B 797 (2003) 131-159.

[70] S. Birnbaum, S. Nilsson, Protein-based capillary affinity gel electrophoresis for the separation of optical isomers, Anal. Chem. 64 (1992) 2872-2874.

[71] S. Declerck, Y. Vander Heyden, D. Mangelings, Enantioseparations of pharmaceuticals with capillary electrochromatography: a review, J. Pharm. Biomed. Anal. 130 (2016) 81-99.

[72] H. Nishi, Enantiomer separation of drugs by electrokinetic chromatography, J. Chromatogr. A 735 (1996) 57-76.

[73] T. Hong, Y. Zheng, W. Hu, Y. Ji, Preparation and evaluation of bovine serum albumin immobilized chiral monolithic column for affinity capillary electrochromatography, Anal. Biochem. 464 (2014) 43-50.

[74] S. Xu, Y. Wang, Y. Tang, Y. Ji, A protein-based mixed selector chiral monolithic stationary phase in capillary electrochromatography, New J. Chem. 42 (2018) 13520-13528. 
[75] D. Wang, X. Song, Y. Duan, L. Xu, J. Zhou, H. Duan, Preparation and characterization of a polystyrene/bovine serum albumin nanoparticlecoated capillary for chiral separation using open-tubular capillary electrochromatography, Electrophoresis 34 (2013) 1339-1342.

[76] J. Yang, D.S. Hage, Chiral separations in capillary electrophoresis using human serum albumin as a buffer additive, Anal. Chem. 66 (1994) 2719-2725.

[77] D. El-Hady, S. Kuhne, N. El-Maali, H. Watzig, Precision in affinity capillary electrophoresis for drug-protein binding studies, J. Pharm. Biomed. Anal. 52 (2010) 232-241.

[78] K. Vuignier, J. Schappler, J.L. Veuthey, P.A. Carrupt, S. Martel, Drug-protein binding: a critical review of analytical tools, Anal. Bioanal. Chem. 398 (2010) 53-66.

[79] Y. Tanaka, S. Terabe, Estimation of binding constants by capillary electrophoresis, J. Chromatogr. B. 768 (2002) 81-92.

[80] Z.M. Li, C.W. Wei, Y. Zhang, D.S. Wang, Y.N. Liu, Investigation of competitive binding of ibuprofen and salicylic acid with serum albumin by affinity capillary electrophoresis, J. Chromatogr. B 879 (2011) 1934-1938.

[81] D.A. El-Hady, H.M. Albishri, Hyphenated affinity capillary electrophoresis with a high-sensitivity cell for the simultaneous binding study of retinol and retinoic acid in nanomolars with serum albumins, J. Chromatogr. B 911 (2012) 180-185.

[82] M.H.A. Busch, L.B. Carels, H.F.M. Boelens, J.C. Kraak, H. Poppe, Comparison of five methods for the study of drug-protein binding in affinity capillary electrophoresis, J. Chromatogr. A 777 (1997) 311-328.

[83] F.B. Erim, J.C. Kraak, Vacancy affinity capillary electrophoresis to study competitive protein-drug binding, J. Chromatogr. B 710 (1998) 205-210.

[84] L. Michalcova, Z. Glatz, Comparison of various capillary electrophoretic approaches for the study of drug-protein interaction with emphasis on minimal consumption of protein sample and possibility of automation, J. Sep. Sci. 38 (2015) 325-331.

[85] A.V. Rudnev, S.S. Aleksenko, O. Semenova, C.G. Hartinger, A.R. Timerbaev, B.K. Keppler, Determination of binding constants and stoichiometries for platinum anticancer drugs and serum transport proteins by capillary electrophoresis using the Hummel-Dreyer method, J. Sep. Sci. 28 (2005) 121-127.

[86] J. Østergaard, N.H.H. Heegaard, Capillary electrophoresis frontal analysis: principles and applications for the study of drug-plasma protein binding, Electrophoresis 24 (2003) 2903-2913.

[87] C. Jiang, D.W. Armstrong, Use of CE for the determination of binding constants, Electrophoresis 31 (2010) 17-27.

[88] R.M. Guijt-van Duijn, J. Frank, G.W.K. van Dedem, E. Baltussen, Recent advances in affinity capillary electrophoresis, Electrophoresis 21 (2000) 3905-3918.

[89] K. Vuignier, J.L. Veuthey, P.A. Carrupt, J. Schappler, Characterization of drugprotein interactions by capillary electrophoresis hyphenated to mass spectrometry, Electrophoresis 33 (2012) 3306-3315. 
[90] Y. Zhang, Y. Sha, K. Qian, X. Chen, Q. Chen, Comparison of three methods for analyzing loureirin $B$ and human serum albumin interaction using capillary electrophoresis, Electrophoresis 38 (2017) 1038-1043.

[91] L. Michalcova, Z. Glatz, Study on the interactions of sulfonylurea antidiabetic drugs with normal and glycated human serum albumin by capillary electrophoresis-frontal analysis, J. Sep. Sci. 39 (2016) 3631-3637.

[92] L. Escuder-Gilabert, Y. Martin-Biosca, M.J. Medina-Hernandez, S. Sagrado, Cyclodextrins in capillary electrophoresis: recent developments and new trends, J. Chromatogr. A 1357 (2014) 2-23.

[93] M.A. Villers, Sur la fermentation de la fecule par l'action du ferment butyrique, Comptes Rendus. 112 (1891) 537.

[94] J. Zhang, P.X. Ma, Cyclodextrin-based supramolecular systems for drug delivery: recent progress and future perspective, Adv. Drug Deliv. Rev. 65 (2013) 1215-1233.

[95] L. Szente, J. Szeman, Cyclodextrins in analytical chemistry: host-guest type molecular recognition, Anal. Chem. 85 (2013) 8024-8030.

[96] Z. Juvancz, R.B. Kendrovics, R. Ivanyi, L. Szente, The role of cyclodextrins in chiral capillary electrophoresis, Electrophoresis 29 (2008) 1701-1712.

[97] M. El-Awady, F. Belal, U. Pyell, Robust analysis of the hydrophobic basic analytes loratadine and desloratadine in pharmaceutical preparations and biological fluids by sweeping-cyclodextrin-modified micellar electrokinetic chromatography, J. Chromatogr. A 1309 (2013) 64-75.

[98] A.M. Stalcup, Chiral separations by capillary electrophoresis, Chiral Anal. (2006) 241-275.

[99] K. `Rezankova, R. Kohoutova, M. Kucha`r, V. Kral, P. `Rezanka, Enantioseparation of novel psychoactive chiral amines and their mixture by capillary electrophoresis using cyclodextrins as chiral selectors, Chem. Pap. 72 (2018) 2737-2743.

[100] X. Deng, Y. Yuan, E. Adams, A. Van Schepdael, Development and validation of a sensitive enantiomeric separation method for new single enantiomer drug levornidazole by CD-capillary electrophoresis, Talanta 106 (2013) 186-191.

[101] M. Resztak, F.K. Glowka, Stereoselective CZE method for analysis of verapamil and norverapamil in human plasma, Acta Polon. Pharmaceutica 70 (2013) 395-401.

[102] M.P. Lorenzo, A. Villase nor, A. Ramamoorthy, A. Garcia, Optimization and validation of a CE-LIF method for amino acids determination in human plasma, Application to bipolar disorder study, Electrophoresis 34 (2013) $1-25$.

[103] H. Zhu, E. Wu, J. Chen, Y.S. Jang, W. Kang, J.K. Choi, W. Lee, J.S. Kang, Reverse migration order of sibutramine enantiomers as a function of cyclodextrin concentration in capillary electrophoresis, J. Pharm. Biomed. Anal. 54 (2011) 1007-1012.

[104] C. Danel, P. Melnyk, N. Azaroual, P.E. Larchanche, J.F. Goossens, C. Vaccher, Evaluation of three neutral capillary coatings for the determination of 
analyte-cyclodextrin binding constants by affinity capillary electrophoresis. Application to $\mathrm{N}, \mathrm{N}^{\prime}$-disubstituted piperazine derivatives, J. Chromatogr. A 1455 (2016) 163-171.

[105] S. Gattu, C.L. Crihfield, G. Lu, L. Bwanali, L.M. Veltri, L.A. Holland, Advances in enzyme substrate analysis with capillary electrophoresis, Methods 146 (2018) 93-106.

[106] M. Shanmuganathan, P. Britz-McKibbin, Inhibitor screening of pharmacological chaperones for lysosomal _-glucocerebrosidase by capillary electrophoresis, Anal. Bioanal. Chem. 399 (2011) 2843-2853.

[107] J.H. Huang, H.P. Chen, A novel capillary electrophoresis-based assay method for coenzyme B 6-dependent diaminopimelate decarboxylase from Propionibacterium acnes, Anal. Methods 5 (2013) 1279-1282.

[108] R.M. Phillips, E. Bair, D.S. Lawrence, C.E. Sims, N.L. Allbritton, Measurement of protein tyrosine phosphatase activity in single cells by capillary electrophoresis, Anal. Chem. 85 (2013) 6136-6142.

[109] S. Iqbal, Nisar-Ur-Rahman, J. Iqbal, A capillary electrophoresis-based enzyme assay for kinetics and inhibition studies of carbonic anhydrase, Anal. Biochem. 444 (2014) 16-21.

[110] K.K. Møller, F.P. Rattray, J.C. Sørensen, Y. Ardo, Comparison of the hydrolysis of bovine _-casein by camel and bovine chymosin: a kinetic and specificity study, J. Agric. Food Chem. 60 (2012) 5454-5460.

[111] R. Nehme, H. Nehme, G. Roux, D. Cerniauskaite, P. Morin, P. Rollin, A. Tatibouet, Contactless conductivity detection for screening myrosinase substrates by capillary electrophoresis, Anal. Chim. Acta 807 (2014) 153-158.

[112] D.M. Liu, Y.P. Shi, J. Chen, Application of capillary electrophoresis in enzyme inhibitors screening, Chin. J. Anal. Chem. 43 (2015) 775-782.

[113] Q. Zhu, X. Huo, S.H. Heinemann, R. Schonherr, R. El-Mergawy, G.K.E. Scriba, Experimental design-guided development of a stereospecific capillary electrophoresis assay for methionine sulfoxide reductase enzymes using a diastereomeric pentapeptide substrate, J. Chromatogr. A 1359 (2014) 224-229.

[114] S. Iqbal, N.U. Rehman, U. Kortz, J. Iqbal, Development of a fast and efficient CE enzyme assay for the characterization and inhibition studies of --glucosidase inhibitors, J. Sep. Sci. 36 (2013) 3623-3628.

[115] J. Bao, F.E. Regnier, Ultramicro enzyme assays in a capillary electrophoretic system, J. Chromatogr. A 608 (1992) 217-224.

[116] B.J. Harmon, I. Leesong, F.E. Regnier, Moving boundary electrophoretically mediated microanalysis, J. Chromatogr. A 726 (1996) 193-204.

[117] S. Van Dyck, A. Van Schepdael, J. Hoogmartens, Michaelis-Menten analysis of bovine plasma amine oxidase by capillary electrophoresis using electrophoretically mediated microanalysis, Electrophoresis 22 (2001) 1436-1442.

[118] L. Asensi-Bernardi, Y. Martin-Biosca, L. Escuder-Gilabert, S. Sagrado, M.J. Medina-Hernandez, Fast evaluation of enantioselective drug metabolism 
by electrophoretically mediated microanalysis: application to fluoxetine metabolism by CYP2D6, Electrophoresis 34 (2013) 3214-3220.

[119] L. Asensi-Bernardi, Y. Martin-Biosca, L. Escuder-Gilabert, S. Sagrado, M.J. Medina-Hernandez, In-line capillary electrophoretic evaluation of the enantioselective metabolism of verapamil by cytochrome P3A4, J. Chromatogr. A 1298 (2013) 139-145.

[120] H. Zhao, Z. Chen, Screening of aromatase inhibitors in traditional Chinese medicines by electrophoretically mediated microanalysis in a partially filled capillary, J. Sep. Sci. 36 (2013) 2691-2697.

[121] H. Ying Kwan, W. Thormann, Electrophoretically mediated microanalysis for characterization of the enantioselective CYP3A4 catalyzed N-demethylation of ketamine, Electrophoresis 33 (2012) 3299-3305.

[122] H. Nehme, R. Nehme, P. Lafite, S. Routier, P. Morin, New development in in-capillary electrophoresis techniques for kinetic and inhibition study of enzymes, Anal. Chim. Acta 722 (2012) 127-135.

[123] H. Nehme, R. Nehme, P. Lafite, E. Duverger, S. Routier, P. Morin, Electrophoretically mediated microanalysis for in-capillary electrical cell lysis and fast enzyme quantification by capillary electrophoresis, Anal. Bioanal. Chem. 405 (2013) 9159-9167.

[124] S.M. Krylova, V. Okhonin, S.N. Krylov, Transverse diffusion of laminar flow profiles - a generic method for mixing reactants in capillary microreactor, J. Sep. Sci. 32 (2009) 742-756.

[125] V. Okhonin, X. Liu, S.N. Krylov, Transverse diffusion of laminar flow profiles to produce capillary nanoreactors, Anal. Chem. 77 (2005) 5925-5929.

[126] S. Fayad, R. Nehme, P. Lafite, P. Morin, Assaying human neutrophil elastase activity by capillary zone electrophoresis combined with laser-induced fluorescence, J. Chromatogr. A 1419 (2015) 116-124.

[127] R. `Reminek, Z. Glatz, W. Thormann, Optimized on-line enantioselective capillary electrophoretic method for kinetic and inhibition studies of drug metabolism mediated by cytochrome P450 enzymes, Electrophoresis 36 (2015) 1349-1357.

[128] M. Cheng, Z. Chen, Trypsin inhibitor screening in traditional Chinese medicine by using an immobilized enzyme microreactor in capillary and molecular docking study, J. Sep. Sci. 40 (2017) 3168-3174.

[129] J. Iqbal, S. Iqbal, C.E. Muller, Advances in immobilized enzyme microbioreactors in capillary electrophoresis, Analyst 138 (2013) 3104-3116.

[130] Z.Y. Wu, H. Zhang, Q.Q. Li, F.Q. Yang, D.Q. Li, Capillary electrophoresis-based online immobilized enzyme reactor for beta-glucosidase kinetics assays and inhibitors screening, J. Chromatogr. B 1110-1111 (2019) 67-73.

[131] J. Schejbal, 'S. 'Sefrana, R. 'Reminek, Z. Glatz, Capillary electrophoresis integrated immobilized enzyme reactor for kinetic and inhibition assays of _-secretase as the Alzheimer's disease drug target, J. Sep. Sci. 42 (2019) 1067-1076. 
[132] H. Zhao, Z. Chen, Screening of neuraminidase inhibitors from traditional Chinese medicines by integrating capillary electrophoresis with immobilized enzyme microreactor, J. Chromatogr. A 1340 (2014) 139-145.

[133] Q.Q. Li, F.Q. Yang, Y.Z. Wang, Z.Y. Wu, Z.N. Xia, H. Chen, Evaluation of thrombin inhibitory activity of catechins by online capillary electrophoresisbased immobilized enzyme microreactor and molecular docking, Talanta 185 (2018) 16-22.

[134] J. Shi, W. Zhao, Y. Chen, L. Guo, L. Yang, A replaceable dual-enzyme capillary microreactor using magnetic beads and its application for simultaneous detection of acetaldehyde and pyruvate, Electrophoresis 33 (2012) 2145-2151.

[135] L. Liu, B. Zhang, Q. Zhang, Y. Shi, L. Guo, L. Yang, Capillary electrophoresisbased immobilized enzyme reactor using particle-packing technique, J. Chromatogr. A 1352 (2014) 80-86.

[136] W. Min, W. Wang, J. Chen, A. Wang, Z. Hu, On-line immobilized acetylcholinesterase microreactor for screening of inhibitors from natural extracts by capillary electrophoresis, Anal. Bioanal. Chem. 404 (2012) 2397-2405.

[137] W. Min, S. Cui, W. Wang, J. Chen, Z. Hu, Capillary electrophoresis applied to screening of trypsin inhibitors using microreactor with trypsin immobilized by glutaraldehyde, Anal. Biochem. 438 (2013) 32-38.

[138] M.A. Camara, M. Tian, X. Liu, X. Liu, Y. Wang, J. Yang, L. Yang, Determination of the inhibitory effect of green tea extract on glucose-6-phosphate dehydrogenase based on multilayer capillary enzyme microreactor, Biomed. Chromatogr. 30 (2016) 1210-1215.

[139] T. Jiang, T. Liang, Y. Wang, W. Zhang, Z. Lv, Immobilized capillary tyrosinase microreactor for inhibitor screening in natural extracts by capillary electrophoresis, J. Pharm. Biomed. Anal. 84 (2013) 36-40. 